\title{
Trade Openness and Disaggregated Import Demand in East African Countries
}

\author{
Micah Samuel Gaalya', Bbaale Edward ${ }^{2}$, Hisali Eria ${ }^{2}$ \\ ${ }^{1}$ Commissioner General's Office, Uganda Revenue Authority, Kampala, Uganda \\ ${ }^{2}$ College of Business and Management Science, Makerere University, Kampala, Uganda \\ Email:mgaalya@gmail.com, ebbaale@bams.mak.ac.ug,ehisali@bams.mak.ac.ug
}

How to cite this paper: Gaalya, M.S., Edward, B. and Eria, H. (2017) Trade Openness and Disaggregated Import Demand in East African Countries. Modern Economy, 8, 667-689.

https://doi.org/10.4236/me.2017.85048

Received: March 11, 2017

Accepted: May 13, 2017

Published: May 16, 2017

Copyright (c) 2017 by authors and Scientific Research Publishing Inc. This work is licensed under the Creative Commons Attribution International License (CC BY 4.0).

http://creativecommons.org/licenses/by/4.0/

Open Access

\begin{abstract}
Despite the well-known gains from trade, the effects of trade openness are a priori ambiguous. For this reason it's important to establish effects of trade openness on both aggregate and disaggregated import demand. This study sought to establish the effects of trade openness on disaggregated imports. A panel data cointegration technique that uses the Fully Modified Ordinally Least Squares and Dynamic Ordinally Least Squares was employed. The data are annual cross country panels of EAC countries covering the period 19942012. The data were obtained from the IMF's International Finance Statistics, the World Bank's World Development Indicators as well as the World Integrated Trade Solution. The findings on the effects of trade openness on import demand show that an increase in the tariff rate reduces imports both at the aggregate and disaggregated levels. An increase in income positively influences the aggregate and disaggregated levels of imports. An increase in prices positively influences the aggregate and disaggregated levels of imports. Exports positively influence the aggregate and disaggregated levels of imports. Lastly the real effective exchange rate negatively influences aggregate and disaggregated imports. The policy implications is that governments of EAC countries could use trade openness reforms, particularly the tariff rate to minimize the importation of goods that can be produced locally, this will help in managing the balance of trade.
\end{abstract}

\section{Keywords}

Trade Openness, Disaggregated Imports, EAC Countries

\section{Introduction}

There has been substantial expansion in trade flows, capital movements as well as mobility of labour across borders over the latter part of the 20th century. During this period world trade has grown from about US \$6.199 trillion in 1994 
to approximately US $\$ 26.02$ trillion in 2012 [1]. For the period, world trade grew nearly twice as fast as world production, signifying that countries are progressively trading with each other. In the case of EAC countries trade in goods and services increased from about US $\$ 4.4$ billion in 1994 to approximately US $\$ 36.78$ billion in 2012 [1]. An examination of the growth rate proposes that EAC countries have a higher trade growth rate in contrast to the world trade. This indicates that for the period, EAC countries trade grew much faster than world trade.

The three major reasons for the growth in world trade are, first, improvements in the technology of transportation and communication, second, increasing convergence of tastes and preference and thirdly, the global economic cooperation that has led to trade openness [1]. In this dissertation, we discuss the influence of trade openness on EAC countries. Theoretically, the influence of trade openness on imports and revenue performance is considered to be an indirect outcome. This indirect outcome is derived from the response of consumption and production decisions to price changes, of which the price changes are triggered by trade reforms [2] and [3]. For example, a reduction in import tariffs is likely to influence imports depending on the elasticity of import demand and price elasticity of supply for import substitutes i.e., if the demand for imports is inelastic it's likely that import volumes will remain unchanged irrespective of the changes in import tariffs and prices. On the other hand, if the demand for imports is elastic it's possible that import volumes will increase owing to changes in import tariffs and prices.

This theoretical relationship has been examined by [4]-[9] among others. An example of studies examining this theoretical literature are presented below; Firstly, [7] analyzing the impact of a reduction of tariff and non-tariff barriers on imports for a panel of selected developing countries shows that income and relatives prices positively influence import growth and that import tariff reduce import growth. It further shows that income and price elasticities are higher as a result of removing barriers to free trade. Overall the study concludes that elimination of barriers to free trade has a strong positive impact on import growth. The shortcoming of this study is that it uses aggregate import elasticities, yet import elasticities differ markedly for different categories of imports.

Secondly, [10] studying the influence of trade openness on disaggregated imports for Ghana shows that trade openness has a positive impact on imports of consumer and intermediate goods but it was found to be insignificant with respect to capital goods. Additionally the study shows that income and price elasticities of consumer and intermediate goods are higher as a result of removing barriers to free trade. Overall the study concludes that elimination of barriers to free trade positively influence import growth of consumer and intermediate goods.

In the case of EAC countries, despite implementing trade openness reforms, hitherto there are no studies that investigated the effects of trade openness on disaggregated imports and different categories of taxes. Studies by [11] have only 
investigated effects of trade openness on aggregate imports and do not consider effects of trade openness on disaggregated imports.

Furthermore, according to [4] the average tariff rate is taken to indicate the level of trade openness for an economy, as such a decline in the average tariff rate is taken to indicate greater trade openness while an increase in the average tariff rate is taken to indicate lower trade openness. From Figure 1 we conclude that EAC countries have experienced a reduction in tariff rates which reflect an increase in the level of trade openness over the period.

Example of trade openness reforms implemented in EAC countries include; implementation of tariff reforms under the World Trade Organization and General Agreement on Tariffs and Trade (GATT), tariff reforms under the IMF and World Bank Structural Adjustment Program and tariff reforms under the EAC customs union protocol [1]. These reforms have involved the reduction of tariff and non-tariff barriers across EAC countries.

Additionally, an analysis of the volume of imports to the EAC countries shows that during the period from 1994 to 2012 imports have dramatically increased from 2002 to 2012 (Figure 2). The increase in imports reflects their growing

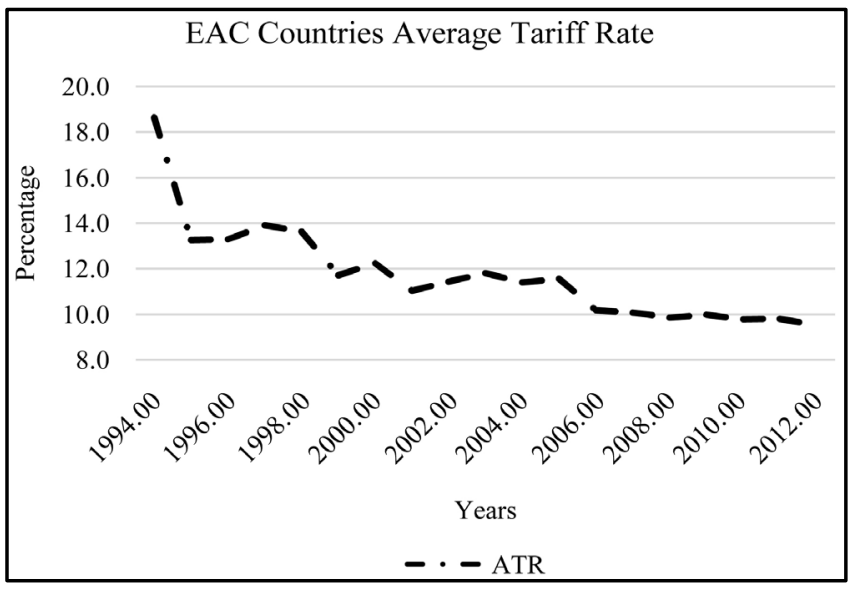

Figure 1. EAC countries average tariff rate. Source: world development indicators, world bank, April 2014.

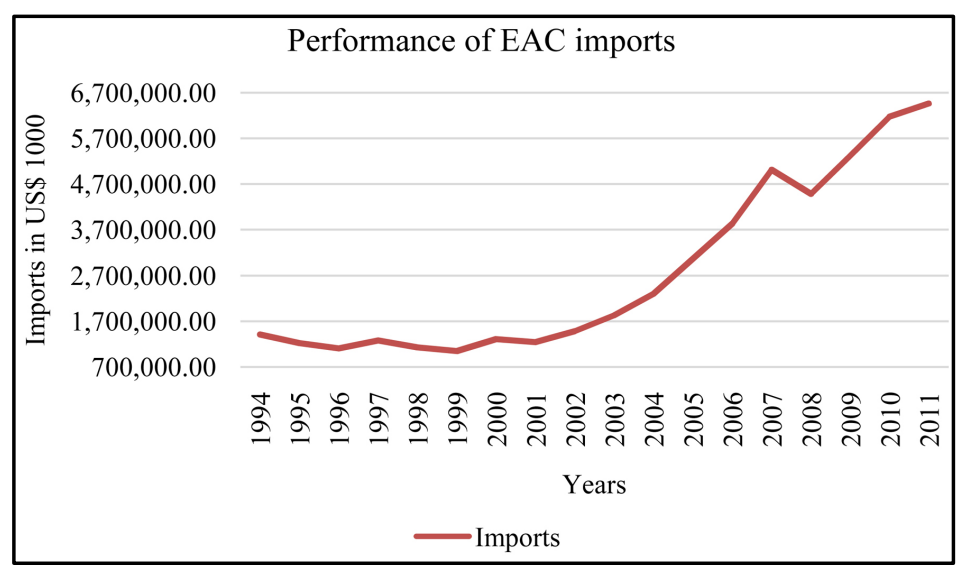

Figure 2. Performance of EAC import in US \$1000. Source: world development indicators, world bank, April 2014. 
importance to EAC countries, similarly the performance of imports measured by the import growth rate shows that for the period from 1994 to 2012, EAC imports grew at 88.3 percent while the sub-Saharan Africa imports grew at 83.1 percent [1]. The higher growth rate of EAC imports suggests that EAC countries are experiencing higher levels of import demand as compared to sub-Saharan African countries.

From literature, it's clear that higher levels of import demand could be driven by increased levels of trade openness. Based on literature this study attempts to answer the question how does trade openness affect disaggregated imports in EAC countries?

\section{Statement of the Problem}

It's argued that the reduction or removal of barrier to free trade, such as import tariffs lowers import prices. The gains from removal of barriers to free trade are expected to increase domestic output through the use of better imported skills and technology to foster high productivity at both firm and industrial level; thereby lowering import for certain categories of imports.

However, in the case of EAC countries, despite implementing trade openness reforms the performance of imports measured by the growth rate shows that EAC countries are experiencing higher import growth as compared to the averaged sub Saharan African countries. This is likely to cause a balance of trade problems, if the high import demand is not managed. For instance; EAC countries will have to review their trade openness policies in order to avoid problems associated with balance of trade deficits such as unemployment, low per capita income, exchange rate shortage, raising inflation, increasing government debt among others. Thus, it's imperative that evidence regarding the influence of trade openness on import demand is provided given the strategic importance of imports to development of EAC countries.

\section{Literature Review}

\subsection{Theoretical Literature on Import Demand}

The theoretical linkage between trade openness and imports has been explained by a range of theories, however there are three leading theories that explain demand for imports. First, is the theory of comparative advantage or neoclassic trade theory, second is the perfect substitute's model or Keynesian trade multiplier and third is the imperfect competition theory also known as the new trade theory [10] and [12].

The first theory is the comparative advantage theory, the theory focuses on how the volume and direction of international trade are affected by changes in relative prices. The volume and direction of trade are explained by differences in factor endowments between countries. The theory is not concerned with the effects of changes in income on trade as the level of employment is assumed to be fixed and output is assumed to be on a given production frontier. This suggests that import demand is based on the assumptions of neoclassic microeconomic 
consumer behavior and general equilibrium theory. The models predict that movement towards openness can temporarily increase imports due to short run gains from re-allocation of resources within the economy. The implication is that trade openness has a positive relationship with imports [7].

The second theory is the perfect substitute's model or Keynesian import demand function, which is based on the macroeconomic multiplier analysis. In this model, relative prices are assumed to be rigid while employment is variable. The model assumes international capital movements which passively adjust to restore the trade balance. The relationship can be defined by the average and marginal propensity to import and the income elasticity of imports. The perfect substitute's model is based on the assumption that traded goods are perfectly substitutes. But in reality, traded goods are not perfect substitutes hence both imported goods and locally produced goods coexist in the same market [10].

The theory assumes that the state intervenes in international trade through the use of trade controls. The theory is based on the assumptions that traded goods are perfectly substitutable and can be traded across countries. The theory further assumes that international capital movements will passively adjust to restore the trade balance and it identifies two mechanisms in which trade openness might affect imports [7]. The first one is the domestic source path, this is associated with innovation while the second one is through absorption of foreign technology from leading trading partners. In the domestic source path, the rate at which imports grow depends on the rate of ingenuity of human capital or innovations in the domestic economy. In the second approach growth in imports depends on how imitation of foreign technology or capital is absorbed in the country [10].

The third theory is the imperfect competition theory. The theory focuses on intra-industry trade and explains the effects of economies of scale, product differentiation and monopolistic competition on international trade. The theory uses three approaches to try and define effects of imperfect competition on international trade these include the Marshallian, Chamberlinian and Cournot approaches. First the Marshallian approach assumes constant returns at the firms level but increasing returns at the industry level, secondly the Chamberlinian approach assumes that an industry consists of many monopolistic firms and new firms are able to enter the market and differentiate their products from existing firms so that any monopoly profit at the industry level is eliminated. Lastly the Cournot approach assumes a market with only a few imperfectly competitive firms where each firm output is taken as given [11].

The theoretical literature suggests three theories that influence import demand, however two theories are commonly used in estimating the import demand function. These are the imperfect substitute model and the perfect substitute model [11]. The perfect substitute's model is based on the assumption that traded goods are perfect substitutes, suggesting that a country can be either an importer or an exporter but not both [13]. But in reality, traded goods are not perfect substitutes hence imported goods and locally produced goods coexist on 
the same market. Furthermore, the increasing trade among nations and existence of intra-industry trade have put question marks on the validity of the perfect substitute's hypothesis. The perfect substitute's model has attracted less attention in the empirical studies since it seems to be less realistic while the imperfect substitution model has received more [10]. The theories assume that in a market economy import demand can be fully modelled by income and relative prices.

\subsection{Empirical Literature on Import Demand}

There are various studies estimating import demand elasticities for different countries. Some of the studies use aggregate analysis whereas others use disaggregate analysis. Some of the studies estimating the aggregate import demand elasticities are reviewed below. First, a study by [10] provides a comprehensive analysis on the drivers of aggregate import demand by focusing on the role of income and prices for a panel of 14 developed countries. The study finds that income seemed to have higher impact on import demand than prices. Another study by [11] evaluates Pakistan's import demand function at an aggregate level for the period 1959 to 1986. The study shows that the aggregate elasticities of income and relative prices were lower than unity at 0.923 for income elasticity and -0.415 for price elasticity.

A study by [14] applied cointegration and error-correction technique to estimate import demand functions. The study investigates the behavior of India's aggregate import demand during the period 1971 to 1995 . The study captures the effect of trade liberalization on imports by including a dummy variable with a value 1 for 1992-1995, the liberalization period and zero otherwise. They found that aggregate import volume was cointegrated with relative import prices and real GDP. In the estimated error correction model, import prices, lags of real GDP and a liberalization dummy were found to be important determinants of import demand function for India, however with a slow speed of adjustment to equilibrium. The import demand in India was largely explained by real GDP but appeared to be less sensitive to import price changes, suggesting that India's imports are non-competitive. An estimate of liberalization dummy was equal to only 0.14 , showing little effect of import liberalization policy on aggregate import volume.

A study by [15] advanced a vector auto regression framework and used quarterly data covering the period 1987 to 2003 to estimate import demand elasticities for the Turkish economy. The study found that both long-run and short run income elasticities were 1.999 and 1.188 for long-run and short-run respectively while the price elasticities were -0.402 for long-run and -0.527 for short run.

Reference [16] estimated a structural import demand function for 77 developing and industrial countries from 1960 to 1993 using cointegration and fully modified ordinary least squares estimator. He found that imports seem to be more responsive to relative prices in the long-run with an average long-run price elasticity of -1.08 while average short-run price elasticity was estimated at -0.26 . 
The study found that imports respond more to income in the long-run than in the short run with average long-run income elasticity equal to 1.45 whereas average short-run income elasticity was equal to 0.45 .

An investigation into the behavior of the import demand function for India using annual data from 1975 to 2003 by [17] shows that economic activity (GDP) import price, foreign exchange reserves and price of domestically produced goods were established as determinants of aggregate import demand. It was found that the aggregated import volume was cointegrated with all variables estimated and the import demand of India was largely explained by price of domestically produced goods, GDP, lag of import and foreign exchange reserves.

Some empirical studies that have used the Autoregressive Distributed Lag (ARDL) bounds test approach to examine import demand functions include; [13] [18] [19] [20] among others. For example, [13] evaluate the stability of the import demand function in Malaysia using the bounds test. The study shows that import demand, income and relative price are found to be cointegrated. The study derives long-run income and relative price elasticities of 1.5 percent and -1.3 percent respectively. A similar study by [18] estimated China's import demand for 1970-1999 using the bounds testing approach to cointegration. In the long-run, he found expenditure on exports having the biggest correlation with imports 0.51 followed by investment expenditure 0.40 . The study concluded that the relative price variable had little impact on the demand for imports.

Furthermore, a study by [19] applied the bounds testing approach to cointegration to estimate the long-run disaggregated import demand model for Fiji using the variables relative prices, total consumption, investment expenditure and export expenditure over the period 1970 to 2000. Their results revealed a long-run cointegration relationship among the variables with import demand elasticities of 0.69 for both export and consumption expenditures and 0.38 for relative prices.

Among the studies conducted on import demand functions for East African countries include studies by [7] [9] [11] among others. A study by [7] investigates the factors that determine bilateral trade between Kenya and Uganda. The study uses import demand functions to estimate each country's import demand elasticities for the period 1969-1989. The data was analyzed using multiple regression estimation technique. The empirical findings show that Kenya's lagged imports had a positive effect on its demand for Ugandan goods while political conflicts exerted a negative influence on its demand. For Uganda, the factors found to be significantly determining the demand for Kenyan goods were income and population with both factors having positive effects on import demand.

A study by [11] estimated co-integrating vector using the Johansen approach. The study shows that in the long-run Uganda's imports are sensitive to changes in output relative prices and foreign exchange availability. In addition the short run output elasticities of imports and real exchange rate are greater than the long-run elasticities. In the short run imports also appeared to be responsive to 
their previous levels but net capital inflows exhibited only long-run potency. The estimated error correction coefficient shows that a large feedback occurs each period.

Some of the studies that have included a trade openness variable in the aggregate import demand function include studies by [7]; [21] among others. For example, [21] provide one of the earliest studies on the impact of trade openness on import demand for a developing economy. In the study trade openness accounts for the response of imports to the elimination of tariff and non-tariff barriers. The study shows that the quantity of restrictions had a significant impact not only on the level of imports but also on income and price variations. The study demonstrated that had the quantity restrictions for consumption goods been lifted in 1985 the date used for the prediction test, their income elasticity would have increased from 0.93 to 1.20 .

Reference [11] used panel data analysis to examine the impact of trade openness on import demand of 22 developing countries. The countries had adopted trade openness policies since the mid-1970s. Using the fixed effects and generalized method of moments (GMM) for panel data analysis, they found that reductions in import duties had significantly affected the growth of imports positively. The impact of a more open trade regime raised import growth and prices through increasing the income and price elasticity of demand for imports.

A similar study by [21] estimates income elasticity, relative price elasticity and trade openness elasticity for Venezuela. The study uses aggregate annual data for the period 1962 to 1979 . The study shows that the price elasticity of import demand was very high at negative 2.086 . While the income elasticity was also found to be higher than unity at 1.879 . The study also shows that trade openness increased import demand for Venezuela.

In contrast to the studies using aggregate analysis other studies have used disaggregated analysis. Some of the studies using disaggregated are reviewed below. Reference [22] using the Johansen-Juselius (JJ) approach estimated the import demand function for Macao by testing both the aggregate and disaggregate import demand models. The study used quarterly data for the period 1970-1986, it observed that cointegration relationships exist in the disaggregate model while no cointegration was found in the aggregate model of Macao's import demand function. The study concluded that the disaggregate model is more appropriate in explaining the import demand for Macao.

A study on the US import demand by [23] estimated a long-run equilibrium relationship between imported consumer goods, relative price of imports and consumption of domestically produced goods. The study found that all these variables are cointegrated. The long-run price elasticity of import demand was estimated at -0.95 , the elasticity of import demand with respect to a permanent increase in real spending was estimated at 2.2. In Clarinda's analysis, he used an econometric equation for estimating the parameters of the demand for imported non-durable consumer goods for the US using quarterly data covering the period 1967 to 1982. 
Reference [24] examines aggregated and disaggregated import demand elasticities for South Africa using cointegration analysis. The study obtains the long-run relationship among the variables with the two-step Engle-Granger technique and a short-run dynamic model. The results show that income elasticity is much larger than price elasticity in the disaggregated import demand elasticities.

Reference [25] examines the demand for imported crude oil in South Africa as a function of income and the price of crude oil over the period 1980-2006. He carried out the Johansen cointegration multivariate analysis to determine the long-run income and price elasticities. He found that a unique long-run cointegration relationship exists between crude oil imports and the explanatory variables. The short run dynamics are estimated by specifying a general error correction model. The estimated long-run price and income elasticities of -0.147 and 0.429 suggest that import demand for crude oil is price and income inelastic. There is also evidence of unidirectional long-run causality running from real GDP to crude oil imports which makes disaggregated elasticities more appropriate.

Some of the studies that have included a trade openness variable in the disaggregate import demand function include studies by [10] and [12] among others. The studies show that the trade openness variable has varying influence of the different import categories. For example a study on Ghana by [10] indicate that trade openness plays a positive significant roles in the short run and long-run demand for machinery and transport equipment while for food and live animals imports are insignificant.

\subsection{Synthesis of Empirical Literature}

The section provides a synthesis of literature on studies investigating aggregate and disaggregate import elasticities. The literature suggests two leading theories that explain demand for import, these are the perfect substitute model and the imperfect substitute model [10]. The perfect substitute's model is based on the assumption that traded goods are perfect substitutes, suggesting that a country can be either an importer or an exporter but not both. On the other hand the imperfect substitution model uses intra-industry trade, product differentiation and monopolistic competition to explain demand for imports i.e., a country is both an importer and an exporter. The perfect substitute's model has attracted less attention in the empirical studies since it seems to be less realistic while the imperfect substitution model has received more attention [10].

The studies have used the following data estimation techniques to estimate import elasticities i.e., Error Correction Model, Vector Error Correction Models, Cointegration technique, Auto Regressive Distributed Lag models, Fixed and Random Effects models as well as the General Method of Moments. The findings shows that aggregate and disaggregated demand for import is explained by income, relative prices, exports, real effective exchange rate, trade openness, government and household expenditure and inflation [2] [4] [5] [6] [7] [8]. Fur- 
thermore, studies on aggregate import elasticities predict that an increase in income, relative import price and trade openness leads to a growth in imports. While studies examining disaggregated import elasticities contend that aggregate import elasticities could behave differently, if import data were to be disaggregated [10] and [12]. This argument provided the motivation for this study to establish the effects of trade opennesss on disaggregated import demand elasticities for the five East African countries.

\section{Methodology for Estimating Import Demand Function}

\subsection{Model Specifications}

According to [10] imports are a function of GDP, imports prices and domestic prices. This relationship is expressed using Equation (1) which is known as the relative import demand function [10]. The formulation assumes instantaneous adjustments by imports resulting from changes in domestic prices and income on the part of the importer.

$$
M_{t}=f\left(P M_{t} / P D_{t}, Y_{t}\right)
$$

where;

$M_{t}=$ Imports.

$P M_{t}=$ Import prices.

$P D_{t}=$ Domestic prices.

$P M_{t} / P D_{t}=$ Relative import prices.

$Y_{t}=$ Gross Domestic Product.

$t=$ is a time subscript

We rewrite Equation (3.1) into an econometric form i.e.,

$$
M_{t}=\alpha_{1}+\alpha_{2}\left(P M_{t} / P D_{t}\right)+\alpha_{3} Y_{t}+e_{t} .
$$

where;

$\alpha_{(1,2 \text { and } 3)}=$ are coefficients for the import demand variables.

$e_{t}=$ is the error term.

The imports are considered as an endogenous variable while the relative import price and GDP are considered as exogenous variables. Equation (2) is transformed into Equation (3) where the variables are transformed into natural logs and also a lag structure is introduced to capture the lagged effect of import demand. The purpose is to make the relationships between variables linear as well as capture the lagged structure of import demand. Hence, the import demand function for consumer, intermediate, capital goods and aggregate goods can be expressed as follows:

$$
\ln M_{t}=a_{1}+a_{2} \ln Y_{t}+a_{3} \ln R P M_{t}+a_{4} \ln M_{t-1}+U_{t}
$$

where,

$\ln M_{t}=$ import categories of consumer, intermediate, capital and aggregate goods.

$\ln M_{t-1}=$ lagged effect of consumer, intermediate, capital and aggregate goods. 
$\ln Y_{t}=$ real GDP at time $t$.

$\ln R P M_{t}=$ relative import prices for the respective import categories i.e., consumer, intermediate, capital and aggregate goods.

$U_{t}=$ the error term.

$t=$ is a time subscript.

To establish the effects of trade openness on imports on EAC countries, we convert model 3.3 to a panel estimation and also introduce the average tariff rate alongside other control variables. These variables are drawn from literature as proposed by [10]; [7] among others. Based on the literature the average tariff rate, export in values and real effective exchange rate are introduced into the standard import demand function in Equation (3). Therefore Equation (3) becomes Equation (4) which is the extended import demand function for a cross country analysis. The equation is expressed as follows:

$\ln M_{i t}=a_{1}+a_{2} \ln Y_{i t}+a_{3} \ln R P M_{i t}+a_{4} \ln A T R_{i t}+a_{5} X_{i t}+a_{6} \ln R E E R_{i t}+a_{7} \ln M_{i t-1}+U_{i t}$

where,

$\ln M_{i t}=$ imports of consumer, intermediate, capital and aggregate goods.

$\ln M_{i t-1}=$ lagged effect of consumer, intermediate, capital and aggregate goods.

$\ln Y_{i t}=$ Real GDP at time $t$.

$\ln R P M_{i t}=$ relative import price for consumer, intermediate, capital and aggregate goods.

$\ln A T R_{i t}=$ average tariff rate.

$\ln X_{i t}=$ exports.

$\ln R E E R_{i t}=$ real effective exchange rate.

$U_{i t}=$ is the error term.

$t=$ is a time subscript.

$i=1,2,3,4,5$.

\subsection{Definition of Variables Used in Import Demand Function}

The variables presented in this section are drawn from theoretical and empirical literature. It's expected that an increase in the income of the importing country will raise import demand substantially. If the income elasticity of import demand is high, other things being equal, this would lead to a deterioration of the balance of payments. However an increase in income may lead to a rise in the production of goods and services domestically. In this case, one may expect imports to fall in the face of an increase in income which means that the relationship between volume of imports and income may be either negative or positive [10]. In the same way, according to [8] studying the influence of trade openness on Venezuela's import performance, they suggest that trade openness can directly affects income and price elasticities i.e., as the degree of import openness increases, the income elasticity of demand increases. That is, the relaxation of controls will tend to increase the income elasticity automatically. Based on the results we assume that income elasticity is positively related to import demand and we expect a positive relationship between import demand and income for 
this study.

According to economic theory as well as studies by [7] import demand is negatively related to relative import price i.e., an increase in prices leads to a decline in import demand. Therefore, from this study we expect that the relative import prices is negatively related to import demand. However contrary to studies by [7], [8] proposes that as economic development proceeds, the price elasticity of import demand also rises implying that import demand is positively related to relative import price. Further analysis should be undertaken to understand the behaviour of disaggregated import elasticities using sector specific data.

We introduce the average tariff rate as a measure for trade openness, this is in line with studies by [7]. A decline in the average tariff rate is taken to indicate greater trade openness and an increase in the average tariff rate is taken to indicate lesser trade openness [4]. According to [7] the average tariff rate is negatively related to import demand. Therefore based on these studies we expect a negative relationship between average tariff rate and import demand. In addition to the average tariff rate we introduce another measure for trade openness as a control variable for the average tariff rate i.e., the trade ratio to GDP. The purpose is to find out whether using another measure of trade openness the results under the average tariff rate variable remain valid. However, the trade ratio to GDP is correlated with import demand as such we cannot use in the import demand functions. In this study we use it as pseudo variable to see if the results under the average tariff rate variable remain valid under another measure for trade openness.

The other variable considered in the extended import demand function is the values of exports. Exports are a crucial component of a country's economy. Not only do exports facilitate international trade, they also stimulate domestic economic activity by creating employment, production, foreign exchange rate and taxes. The ability to export goods helps an economy to grow, by selling more goods and services. Reference [7] using a sample of 46 sub-Saharan countries conclude that exports are positively related import demand. They show that exports represent efficiency gains and economies of scale on the part of domestic producers which enables domestic producers penetrate the international market. Therefore an increase in exports is expected to increase demand for intermediate and capital goods imports used in production of export goods. Based on the study by [12] we expect a positive relationship between exports and import demand.

We also include the real effective exchange rate into the extended import demand function. The use of the real effective exchange rate variable is in line with studies by [16]. The real effective exchange rate, is the weighted average of a country's currency relative to an index or basket of other major currencies adjusted for the effects of inflation. Movements in the real effective exchange rate affect resource allocation by changing the country's competitiveness in international trade. An increase in real effective exchange rate is expected to lead to a 
decrease in import demand. Accordingly a negative relationship is expected between real effective exchange rate and import demand.

\subsection{Data Type and Sources}

This section provides a description of the data appearing in the four import demand equations. The study employs a cross country panel which includes the following countries, Burundi, Kenya, Rwanda, Tanzania and Uganda. The following explanatory variables are used to explain aggregate and disaggregated import demand; Real GDP per capita, relative import prices for the different import categories, average tariff rate, trade ratio to GDP, exports and real effective exchange rate. Data on imports of aggregate goods (M), consumer goods (Co), intermediate goods (I) and capital goods (K) were obtained from the World Bank's World Integrated Trade Solution (WITS). Data on the GDP per capita, average tariff rate and exports was obtained from the World Bank's World Development Indicators (WDI). Data on the relative import price (RPM) and the real effective exchange rate (REER) was obtained from the IMF's International Finance Statistics (IFS) Table 1.

Table 1. Description of the data used in import models.

\begin{tabular}{|c|c|}
\hline Variable & Source \\
\hline $\begin{array}{l}\text { Imports }(\mathrm{M}) \text { of aggregate goods } \\
\text { and services }\end{array}$ & $\begin{array}{c}\text { Constant } 2000 \text { US Dollars (USD), Source; WITS, } \\
\text { World Bank, April } 2014 .\end{array}$ \\
\hline $\begin{array}{l}\text { Import of consumer goods and } \\
\text { services }(\mathrm{Co})\end{array}$ & $\begin{array}{c}\text { Constant } 2000 \text { US Dollars (USD), Based on the Broad } \\
\text { Economic Categories (BEC) Source; WITS, } \\
\text { World Bank, April } 2014\end{array}$ \\
\hline $\begin{array}{l}\text { Import of intermediate goods } \\
\text { and services (I) }\end{array}$ & $\begin{array}{l}\text { Constant } 2000 \text { US Dollars (USD), Based on the } \\
\text { Broad Economic Categories (BEC) Source; } \\
\text { WITS, World Bank, April } 2014\end{array}$ \\
\hline $\begin{array}{l}\text { Imports of capital goods and } \\
\text { services }(\mathrm{K})\end{array}$ & $\begin{array}{l}\text { Constant } 2000 \text { US Dollars (USD), Based on the } \\
\text { Broad Economic Categories (BEC) Source; } \\
\text { WITS, World Bank, April } 2014\end{array}$ \\
\hline Real GDP per capita (Y) & $\begin{array}{l}\text { Constant } 2000 \text { US Dollars (USD). Source; World Bank, } \\
\text { World Development Indicators (WDI), July } 2014 .\end{array}$ \\
\hline Relative import price (RPM). & $\begin{array}{l}\text { International Monetary Fund's (IMF) International } \\
\text { Finance Statistics (IFS), July 2014. Constructed by } \\
\text { dividing imports prices by domestic prices. }\end{array}$ \\
\hline Average tariff rate (ATR) & $\begin{array}{l}\text { Weighted average tariff rate. Source; World Bank, } \\
\text { World Development Indicators (WDI), July } 2014 .\end{array}$ \\
\hline Trade ratio to GDP & $\begin{array}{l}\text { World Bank, World Development } \\
\text { Indicators (WDI), July } 2014 .\end{array}$ \\
\hline Exports in values (X) & $\begin{array}{l}\text { World Bank, World Development } \\
\text { Indicators (WDI), July } 2014 .\end{array}$ \\
\hline $\begin{array}{l}\text { Real effective exchange rate } \\
\text { (REER) }\end{array}$ & $\begin{array}{c}\text { International Monetary Fund's (IMF) International Finance } \\
\text { Statistics (IFS), July 2014. Constructed by dividing } \\
\text { disaggregated imports by the price indices. }\end{array}$ \\
\hline
\end{tabular}


The use of panel data offers several advantages in econometric analysis, first, panel data contains more degrees of freedom and more sample variability, hence improving the efficiency of econometric estimates. Second, panel data has a greater capacity for capturing the complexity of import demand behavior than a single time series data. It is frequently argued that the reason that a researcher finds or does not find certain causal effects in econometric analysis is due to omission of certain variables in one's model specification which are correlated with the included explanatory variables. However, since panel data contain information on both the inter-temporal dynamics and the individuality of the entities, it is capable of controlling for the effects of missing or unobserved variables.

Reference [26] argues that panel data generates more accurate predictions for individual outcomes by pooling the data rather than generating predictions of individual outcomes. If individual behaviors are similar on certain variables, panel data provides the possibility of learning an individual's behavior by observing the behavior of others. Thus, it is possible to obtain a more accurate description of an individual's behavior by supplementing observations of the individual in question with data on other individuals.

\section{Empirical Results}

The study uses Stata 14 to estimate the panel unit root tests, panel cointegration test as well as the related import demand panel cointegration regressions i.e., consumer, intermediate, capital and aggregate goods.

\subsection{Panel Unit Root Tests}

The first step in the analysis is to ascertain the order of integration of the variables. We use two panel unit root tests to establish the orders of integration of the variables. We use a panel unit root test that allows for cross sectional dependence and another that allows for cross sectional independence. A variable is integrated of order $\mathrm{d}$, written as $\mathrm{I}(\mathrm{d})$, if it requires differencing $\mathrm{d}$ times before it becomes stationary. To test the variables order of integration, we use the [27]; [28] panel unit root tests.

The imports of aggregate goods, consumer goods, intermediate goods and capital goods are taken as dependent variables while the per capital GDP, relative import price, average tariff rate, real effective exchange rate, exports are taken as independent variables. Imports and the respective relative import prices are transformed into natural logarithms to make the relationships between variables linear. If the data series is stationary at level, it is called I(0) if the data series is stationary at first difference, it's referred to as integrated of order one, i.e., I(1) and if the data series is stationary at second difference, then it's referred to as integrated of order two, i.e., I(2). First, we perform unit root tests at levels and where necessary we carry out higher order tests. The results for the [27] and [28] panel unit root test are presented below in Table 2.

The results under Table 2 show that the T-bar and the w (T-bar) test statistic of [27] panel unit root test fail to reject the null hypothesis of presence of unit 
Table 2. Panel unit root test.

\begin{tabular}{|c|c|c|c|c|}
\hline \multirow[b]{2}{*}{ Variable } & \multicolumn{2}{|c|}{ Im, et al. (2003) } & $\begin{array}{l}\text { Maddala and Wu } \\
\text { (1999) }\end{array}$ & $\begin{array}{l}\text { Order of } \\
\text { integration }\end{array}$ \\
\hline & T-bar & Z (T-bar) & $\begin{array}{l}\text { Modified Chi } \\
\text { Squared Pm }\end{array}$ & \\
\hline Consumer goods & -1.13 & 0.911 & -1.66 & \multirow{2}{*}{$\mathrm{I}(1)$} \\
\hline$\Delta$ Consumer goods & $-4.35^{\star}$ & $-4.59^{\star}$ & $6.11^{*}$ & \\
\hline Intermediate goods & -0.903 & 1.49 & -1.67 & \multirow{2}{*}{$\mathrm{I}(1)$} \\
\hline$\Delta$ Intermediate goods & $-4.19^{\star}$ & $-4.39^{*}$ & $5.43^{*}$ & \\
\hline Capital goods & -1.03 & -1.107 & -1.71 & \multirow{2}{*}{$\mathrm{I}(1)$} \\
\hline$\Delta$ Capital goods & $-4.61^{*}$ & $-4.78^{*}$ & $11.0^{*}$ & \\
\hline Aggregate goods & -0.14 & 3.62 & -1.18 & \multirow{2}{*}{$\mathrm{I}(1)$} \\
\hline$\Delta$ Aggregate goods & $-3.86^{\star}$ & $-4.09^{*}$ & $4.29^{*}$ & \\
\hline GDP per capita & -0.958 & -1.403 & 1.10 & \multirow{2}{*}{$\mathrm{I}(1)$} \\
\hline$\Delta \mathrm{GDP}$ per capita & $-3.03^{\star}$ & $-2.39^{\star}$ & $1.34^{*}$ & \\
\hline Average tariff rate & $-5.91^{\star}$ & $-5.24^{*}$ & $2.39^{*}$ & $\mathrm{I}(0)$ \\
\hline $\begin{array}{l}\text { Consumer goods relative } \\
\text { import price }\end{array}$ & $-2.209^{\star}$ & $-1.871^{\star}$ & $2.83^{*}$ & $\mathrm{I}(0)$ \\
\hline $\begin{array}{l}\text { Intermediate goods } \\
\text { relative import price }\end{array}$ & $-2.358^{\star}$ & $-1.459^{*}$ & $4.53^{*}$ & $\mathrm{I}(0)$ \\
\hline $\begin{array}{l}\text { Capital goods } \\
\text { relative import price }\end{array}$ & $-2.644^{\star}$ & $-2.361^{\star}$ & $4.34^{*}$ & $\mathrm{I}(0)$ \\
\hline $\begin{array}{l}\text { Aggregate goods relative } \\
\text { import price }\end{array}$ & $-2.173^{\star}$ & $-1.066^{*}$ & $3.85^{*}$ & $\mathrm{I}(0)$ \\
\hline Exports & $-4.240^{\star}$ & $-4.525^{\star}$ & $5.54^{*}$ & $\mathrm{I}(0)$ \\
\hline REER & -1.271 & 0.543 & $-0.71^{\star}$ & \multirow{2}{*}{$\mathrm{I}(1)$} \\
\hline$\triangle \mathrm{REER}$ & $-0.462^{\star}$ & $2.669^{*}$ & $-1.94^{\star}$ & \\
\hline
\end{tabular}

We use constant \& trend as deterministic terms. We use two lag for consumer goods, intermediate goods, capital goods, aggregate goods, relative import prices, exports and GDP per capita. On the other hand we use a lag of 1 for the real effective exchange rate and the average tariff rate for the IPS and Fisher-ADF Test. $\left.{ }^{*}\right)$ denotes rejection of the null hypothesis at $99 \%$.

roots at level for the following variables; aggregate goods, consumer goods, intermediate goods, capital goods, real effective exchange rate and GDP per capita. This suggests that the variables are non-stationary at level. On the contrary the [28] unit root tests rejects the null hypothesis of presence of a unit root at level for the relative import price, exports and average tariff rate. This suggests that the variables are stationary at level. When the non-stationary variables i.e., aggregate goods, consumer goods, intermediate goods, capital goods, real effective exchange rate and GDP per capita are transformed to first difference. The [28] panel unit root test rejects the null hypothesis of presence of a unit root which implies that the variables are stationary after first differencing and hence integrated of order one I(1).

The results of the [28] panel unit root test under Table 2 shows that the Modified Chi Squared Pm panel unit root test are similar to the [27] panel unit root 
test. From the results, we conclude that some of the variables are stationary at level I(0) while others are stationary at first difference (1). The variables are not integrated of the same order suggesting that we need to deploy a panel regression technique that estimates variables integrated of different orders.

\subsection{Panel Cointegration Test}

In testing for cointegration in panel data, we use the Kao panel cointegration tests. The test is suitable for panels with small $\mathrm{T}$. The results from the four import models show that the ADF test statistic rejects the null hypothesis of no cointegration at 1 percent level of significance. This implies that there exists a long-run relationship in the variables. From the results we conclude that the variables in the four import demand functions have a long-run cointegration relationship.

\subsection{Panel Cointegration Regressions}

The results from the panel unit roots test and the panel cointegration tests show that the variables across the four import models are integrated of $\mathrm{I}(0)$ and $\mathrm{I}(1)$ but also cointegrated. According to [26] the asymptotics of large $\mathrm{T}$, large $\mathrm{N}$ panels are different from the asymptotics of small $\mathrm{T}$ and small $\mathrm{N}$ panels. Therefore estimations for small $\mathrm{T}$ and small $\mathrm{N}$ panels rely on Fixed or Random effects estimator if the variables are integrated of the same order and also cointegrated. On the other hand if the variables are not integrated of the same order and or cointegrated, the small $\mathrm{T}$ and small $\mathrm{N}$ panels rely on the Fully-Modified Ordinally Least Squares (FMOLS) and Dynamic Ordinally Least Squares (DOLS). Estimations for small $\mathrm{T}$ and large $\mathrm{N}$ panels rely on a combination of fixed effects estimators and instrumental variable estimators, such as the [29] generalized method-of-moments estimator. The large $\mathrm{N}$ and large $\mathrm{T}$ panel estimations, rely on the mean-group (MG) and pooled mean-group (PMG) estimators.

In our specific case i.e., $\mathrm{T}=19$ and $\mathrm{N}=5$. We have a relatively small $\mathrm{T}$ and small $\mathrm{N}$ panel that is integrated of $\mathrm{I}(0)$ and $\mathrm{I}(1)$ but cointegrated. From the literature we adopt the FMOLS and DOLS estimators. Pedroni (2000) shows that the FMOLS and DOLS estimators performs well in small samples. The FMOL and DOLS model is considered superior to other estimation techniques because it inherently correct for endogeneity, serial correlation and asymptotic bias.

\subsection{Discussion of Empirical Results}

Table 3 and Table 4 shows the empirical results from estimating the standard and extended FMOLS and DOLS import demand models We use consumer, intermediate, capital and aggregate goods as dependent variables for the import models. Whereas GDP per capita and relative import price are used as independent variables in standard import models Table 3. We introduce average tariff rate, exports and real effective exchange rate as independent variables in the extended import models. The discussion is based on the results presented in the extended import models in Table 4. The results are considered more robust than 
Table 3. Standard FMOLS and DOLS import models.

\begin{tabular}{|c|c|c|c|c|c|c|c|c|}
\hline & (1) & (2) & (3) & (4) & (5) & (6) & (7) & (8) \\
\hline \multirow[t]{2}{*}{ VARIABLES } & Consumer & Consume & ntermedia & termediate & Capital & Capital & Aggregate & Aggregate \\
\hline & FMOLS & DOLS & FMOLS & DOLS & FMOLS & DOLS & FMOLS & DOLS \\
\hline \multirow[t]{2}{*}{$\begin{array}{l}\text { GDP per } \\
\text { capita }\end{array}$} & $1.857^{\star}$ & $1.4623^{\star}$ & $1.8500^{*}$ & $1.6855^{\star}$ & $1.8167^{\star}$ & $1.6831^{*}$ & $1.8975^{\star}$ & $1.5208^{\star}$ \\
\hline & $(0.191)$ & $(0.296)$ & $(0.168)$ & $(0.198)$ & $(0.199)$ & $(0.238)$ & $(0.046)$ & $(0.242)$ \\
\hline \multirow[t]{2}{*}{$\begin{array}{c}\text { Relative } \\
\text { import price }\end{array}$} & $0.169^{*}$ & $0.3915^{\star}$ & $0.1251^{\star}$ & $0.2470^{*}$ & $0.1576^{*}$ & $0.2540^{*}$ & $0.1594^{\star}$ & $0.3583^{*}$ \\
\hline & $(0.046)$ & $(0.110)$ & $(0.043)$ & $(0.075)$ & $(0.050)$ & $(0.086)$ & $(0.186)$ & $(0.088)$ \\
\hline Observations & 95 & 95 & 95 & 95 & 95 & 95 & 95 & 95 \\
\hline $\mathrm{R}$-squared & 0.94 & 0.97 & 0.94 & 0.98 & 0.94 & 0.98 & 0.95 & 0.98 \\
\hline
\end{tabular}

Note: Standard errors in parentheses ${ }^{* *} \mathrm{p}<0.10,{ }^{* *} \mathrm{p}<0.05,{ }^{*} \mathrm{p}<0.01$. The dependent variable for Models (1) and (2) is consumer goods (3) and (4) intermediate goods (5) and (6) capital goods while (7) and (8) is aggregate goods. The relative import price variables represents the respective relative import prices for consumer, intermediate, capital and aggregate good.

Table 4. Extended FMOLS and DOLS import models with average tariff rate.

\begin{tabular}{|c|c|c|c|c|c|c|c|c|}
\hline & $(1)$ & (2) & (3) & (4) & (5) & (6) & (7) & (8) \\
\hline \multirow[t]{2}{*}{ VARIABLES } & \multicolumn{8}{|c|}{ ConsumerConsumerIntermediateIntermediate Capital CapitalAggregateAggregate } \\
\hline & FMOLS & DOLS & FMOLS & DOLS & FMOLS & DOLS & FMOLS & DOLS \\
\hline \multirow{3}{*}{$\begin{array}{c}\operatorname{Lag}(1) \\
\text { dependent } \\
\text { variable }\end{array}$} & & & & & & & & \\
\hline & $0.687^{*}$ & $0.466^{*}$ & $0.564^{*}$ & $0.401^{*}$ & & & $0.633^{*}$ & 0.412 \\
\hline & $(0.069)$ & $(0.071)$ & $(0.064)$ & $(0.067)$ & & & $(0.079)$ & $(0.084)$ \\
\hline \multirow[t]{2}{*}{ GDP per capita } & $0.099^{*}$ & $0.405^{\star}$ & $0.131^{\star}$ & $0.398^{\star}$ & $0.230^{\star}$ & 0.257 & $0.073^{\star}$ & 0.215 \\
\hline & $(0.182)$ & $(0.187)$ & $(0.147)$ & $(0.155)$ & $(0.309)$ & $(0.298)$ & $(0.196)$ & $(0.209)$ \\
\hline \multirow[t]{2}{*}{$\begin{array}{c}\text { Relative import } \\
\text { prices }\end{array}$} & $0.099^{*}$ & $0.105^{\star}$ & $0.042^{\star}$ & $0.039^{* *}$ & $0.155^{*}$ & $0.131^{*}$ & $0.089^{*}$ & $0.088^{\star}$ \\
\hline & $(0.022)$ & $(0.023)$ & $(0.019)$ & $(0.020)$ & $(0.038)$ & $(0.041)$ & $(0.024)$ & $(0.025)$ \\
\hline \multirow[t]{2}{*}{ Exports } & $0.337^{*}$ & $0.414^{\star}$ & $0.379^{*}$ & $0.439^{*}$ & $0.776^{*}$ & $0.724^{*}$ & $0.405^{\star}$ & $0.478^{\star}$ \\
\hline & $(0.091)$ & $(0.093)$ & $(0.071)$ & $(0.075)$ & $(0.134)$ & $(0.133)$ & $(0.094)$ & $(0.100)$ \\
\hline \multirow[t]{2}{*}{$\begin{array}{l}\text { Average tariff } \\
\text { rate }\end{array}$} & $-0.013^{* *}$ & $-0.013^{*}$ & $-0.011^{\star}$ & $-0.009^{* *}$ & $-0.019^{\star *}$ & -0.015 & $-0.01^{\star *}$ & $-0.012^{*}$ \\
\hline & $(0.006)$ & $(0.006)$ & $(0.005)$ & $(0.005)$ & $(0.010)$ & $(0.010)$ & $(0.006)$ & $(0.007)$ \\
\hline \multirow[t]{2}{*}{ REER } & $-0.156^{*}$ & $-0.125^{\star}$ & $-0.124^{\star}$ & -0.051 & $-0.230^{*}$ & $-0.22^{*}$ & $-0.083^{\star}$ & -0.075 \\
\hline & $(0.043)$ & $(0.044)$ & $(0.035)$ & $(0.036)$ & $(0.073)$ & $(0.069)$ & $(0.047)$ & $(0.050)$ \\
\hline R-squared & 0.97 & 0.97 & 0.98 & 0.98 & 0.96 & 0.95 & 0.98 & 0.98 \\
\hline
\end{tabular}

Note: Standard errors in parentheses ${ }^{* *} \mathrm{p}<0.10,{ }^{* *} \mathrm{p}<0.05,{ }^{*} \mathrm{p}<0.01$. The dependent variable for Models (1) and (2) is consumer goods (3) and (4) intermediate goods (5) and (6) capital goods while (7) and (8) is aggregate goods. The relative import price variables represents the respective relative import prices for consumer, intermediate, capital and aggregate goods.

results in Table 3.

The results under Table 4 establish the effects of trade openness on aggregate and disaggregated import elasticities for EAC countries. We use the FMOL and 
DOLS panel data analysis techniques to estimate models $1,2,3,4,5,6,7$ and 8 which is an important contribution of the paper to the import demand and trade openness literature.

The results under Table 4 show that the coefficient of GDP per capita or income elasticity across the aggregate and disaggregated import models are positive and statistically significant. The positive relationship implies that an increase in GDP per capita increases imports of aggregate and disaggregated goods. Additionally, the aggregate and disaggregated income elasticity are inelastic and concentrated between 0.40 and 0.07 range. The size of the disaggregate income elasticity are relatively higher than aggregate import income elasticity which reinforces the assumption that disaggregated import elasticities differ markedly from aggregate import elasticities. Furthermore, the disaggregated income elasticities show that consumer goods have the highest income elasticity, this is followed by intermediate goods, capital goods and lastly aggregate goods. This result suggests that GDP per capita has a higher influence on consumer goods as compared to capital and intermediate goods. The results is expected and are in line with study findings by [7] who used aggregate and disaggregated import elasticities for a panel of 22 developing countries. However the magnitude of income elasticities computed in this study appear lower than elasticities computed by [7]. The lower elasticities could be attributed to disaggregation of data as well as lower incomes experienced in EAC countries. In the same way, this findings renders support to [8] first hypothesis which predicts that as the degree on trade openness increases, the income elasticity of import demand also increases.

The coefficient of relative import price or price elasticity across the four models is positive and statistically significant. The positive relationship implies that an increase in relative import prices increases imports of aggregate and disaggregated goods. The results shows that the price elasticities are inelastic and concentrated between 0.15 and 0.09 range. Furthermore, disaggregated price elasticities show that consumer goods have the highest price elasticity, followed by capital goods and lastly intermediate goods. These result contradicts economic theory which predicts that as prices increase demand for goods decreases. This result is not expected but it is supported by findings from [8] [10] [11] among others. The findings in the three studies shows that import demand increased with an increase in the relative import prices for these countries in the 1970's i.e., Hondurus, Syria, India, Venezuela and Nigeria. These results suggest that trade openness makes it easier to substitute domestic production for import substitutes thereby imports increasing prices on the domestic market. However, given that these results contradict economic theory, we recommend that these finding are further analyzed using more detailed sector specific data to establish the behaviour of disaggregated import elasticities

The results of the first lag of the consumer, intermediate and aggregate good models are positive and statistically significant. This result implies that imports of consumer, intermediate and aggregate goods in the previous period are an 
important determinant for imports in the present period. This result supports economic theory which predicts that demand for imports in the previous period influence demand for imports in the current period [11]. Furthermore, the elasticity are concentrated between 0.68 and 0.40 range, suggesting a comparable influence of the first lag import elasticity on the four import categories.

The coefficient of average tariff rate which is used as a measure for trade openness is negative and statistically significant for the aggregate and disaggregated import models. The negative relationship implies that an increase in the tariff rate leads to decrease imports of aggregate and disaggregated goods. The average tariff rate elasticity are inelastic and concentrated between -0.009 and -0.019 range. The results are expected and are in line with theoretical literature which predicts that a decrease in tariff rates leads to an increase in import demand [7]. On the other hand the magnitude of these tariff elasticities appear lower than elasticities computed by [7] suggesting a smaller influence of reducing tariff rate on imports of EAC countries. Consumer goods have the highest average tariff rate elasticity, followed by capital goods and lastly intermediate goods. These results are also consistent with the study findings by [11] which further supports our study predictions.

As a robustness test, in Table 5 we control for the results of the average tariff rate variable by introducing another measure for trade openness i.e., the trade ratio to GDP. This variable is used for a robustness test since it's correlated with

Table 5. Extended FMOLS and DOLS import models with trade ratio to GDP.

\begin{tabular}{|c|c|c|c|c|c|c|c|c|}
\hline & (1) & (2) & (3) & (4) & (5) & (6) & (7) & (8) \\
\hline \multirow[t]{2}{*}{ VARIABLES } & Consumer & Consumer & Intermediate & Intermediate & Capital & Capital & Aggregate & Aggregate \\
\hline & FMOLS & DOLS & FMOLS & DOLS & FMOLS & DOLS & FMOLS & DOLS \\
\hline \multirow[t]{2}{*}{$\begin{array}{l}\text { Lag (1) dependent } \\
\text { variable }\end{array}$} & $0.643^{\star}$ & $0.432^{*}$ & $0.506^{\star}$ & $0.506^{\star}$ & $0.446^{*}$ & $0.281^{\star}$ & $0.566^{*}$ & $0.357^{\star}$ \\
\hline & $(0.066)$ & $(0.072)$ & $(0.066)$ & $(0.066)$ & $(0.119)$ & $(0.126)$ & $(0.075)$ & $(0.077)$ \\
\hline \multirow[t]{2}{*}{ GDP per capita } & $0.642^{*}$ & $0.432^{*}$ & $0.613^{*}$ & $0.665^{\star}$ & $0.261^{\star \star}$ & $0.298^{\star}$ & $0.790^{*}$ & $0.572^{\star}$ \\
\hline & $(0.136)$ & $(0.071)$ & $(0.125)$ & $(0.132)$ & $(0.107)$ & $(1.048)$ & $(0.135)$ & $(0.175)$ \\
\hline \multirow[t]{2}{*}{ Relative import prices } & $0.0871^{\star * *}$ & $0.106^{*}$ & 0.0747 & $0.043^{\star}$ & $0.0848^{\star *}$ & $0.0478^{\star}$ & 0.0797 & $0.088^{\star}$ \\
\hline & $(0.048)$ & $(0.022)$ & $(0.0465)$ & $(0.019)$ & $(0.0377)$ & $(0.673)$ & $(0.0491)$ & $(0.022)$ \\
\hline \multirow[t]{2}{*}{ Exports } & $0.509^{*}$ & $0.198^{*}$ & $0.563^{\star}$ & $0.267^{\star}$ & $0.647^{\star}$ & $0.655^{\star}$ & $0.539^{*}$ & $0.231^{*}$ \\
\hline & $(0.0640)$ & $(0.008)$ & $(0.0620)$ & $(0.070)$ & $(0.0545)$ & $(0.726)$ & $(0.0646)$ & $(0.087)$ \\
\hline \multirow[t]{2}{*}{ Trade ratio to GDP } & $0.0153^{*}$ & $0.008^{*}$ & $0.010^{*}$ & $0.008^{*}$ & $0.021^{*}$ & 0.022 & $0.013^{*}$ & $0.011^{*}$ \\
\hline & $(0.0045)$ & $(0.002)$ & $(0.004)$ & $(0.002)$ & $(0.003)$ & $(0.043)$ & $(0.004)$ & $(0.002)$ \\
\hline \multirow[t]{2}{*}{ REER } & $-0.242^{*}$ & $-0.050^{*}$ & $0.071^{* * *}$ & $-0.007^{\star}$ & $-0.144^{*}$ & 0.144 & $-0.165^{\star}$ & -0.004 \\
\hline & $(0.0431)$ & $(0.041)$ & $(0.0399)$ & $(0.033)$ & $(0.034)$ & $(0.353)$ & $(0.0423)$ & $(0.042)$ \\
\hline Observations & 95 & 95 & 95 & 95 & 95 & 95 & 95 & 95 \\
\hline R-squared & 0.936 & 0.962 & 0.867 & 0.971 & 0.960 & 0.978 & 0.902 & 0.965 \\
\hline
\end{tabular}

Note: Standard errors in parentheses ${ }^{* *} \mathrm{p}<0.10,{ }^{* *} \mathrm{p}<0.05,{ }^{*} \mathrm{p}<0.01$. The dependent variable for Models (1) and (2) is consumer goods (3) and (4) intermediate goods (5) and (6) capital goods while (7) and (8) is aggregate goods. The relative import price variables represents the respective relative import prices for consumer, intermediate, capital and aggregate goods. 
import demand. The purpose is to find out whether using another measure of trade openness the results remain valid. The results from this measure show that with respect to aggregate and disaggregated goods the coefficient for trade ratio to GDP is positive and statistically significant. This results supports results obtained under the average tariff rate which implies that trade openness positively influences import demand. The results are expected and are in line with theoretical and empirical literature which predicts that an increase in trade openness leads to an increase in import demand [7] and [10]. The overall implication of these finding is that trade openness has led to an increase in import demand for the five EAC countries.

The coefficient for exports is positive and statistically significant for the aggregate and disaggregated import models. The positive relationship implies that an increase in exports increases imports of aggregate and disaggregated goods. The export elasticity are inelastic and concentrated between 0.77 and 0.33 range. The size of the disaggregate export elasticities are higher than aggregate export elasticities, which suggests that aggregated elasticities could mask important characteristics in data [10]. Capital goods have the highest export elasticity, while intermediate and consumer goods have similar elasticities. These result predicts that an increase in exports is likely to increase more demand for imports of capital goods as compared to consumer and intermediate goods. The results are expected and are in line with theoretical and empirical literature which predicts that a growth in exports leads to an increase demand for goods used in the production process such as imports of intermediate goods [10]. However the size of export elasticities computed in this study appear lower than elasticities computed by [7]. The lower elasticities could be attributed to disaggregation of data as well as lower incomes experienced in EAC countries. The overall implication of these findings is that exports lead to an increase in import demand for EAC countries.

The coefficient of real effective exchange rate is negative and statistically significant for the aggregate and disaggregated import models. The negative relationship implies that an increase in the real effective exchange rate decreases imports of aggregate and disaggregated goods. The results are expected and are in line with empirical literature by [12]; [9] and [13] who predicts that an increase in exchange rate leads to a decrease in import demand. The computed real effective exchange rate elasticities are inelastic and concentrated between -0.009 and -0.019 range. The size of the disaggregate real effective exchange rate elasticities are higher than aggregate price elasticities, which supports the assumption that disaggregated import elasticities mask important characteristics in data. The disaggregated import elasticities appear similar suggesting a comparable influence of the real effective exchange rate on disaggregated imports. Capital goods have the highest real effective exchange rate elasticity, followed by consumer goods and lastly intermediate goods. These results are expected and are in line with the study predictions. The size of the real effective exchange rate elasticity are bigger than elasticities computed by [9] for Kenya and Uganda 
during the early stages of EAC integration. On the other hand the real effective exchange rate elasticities computed in this study are lower than elasticities computed for developed countries. The overall implication of this finding is that real effective exchange rate has led to a decrease in import demand for the five EAC countries.

\section{Conclusions and Policy Recommendations}

\subsection{Conclusions}

Despite the well-known gains from trade, the effects of trade openness are a priori ambiguous. For this reason it's important to establish effects of trade openness on both aggregate and disaggregated import demand for any country opening its borders to trade. This paper establishes the effects of trade openness on aggregate and disaggregated import elasticities for EAC countries. The paper uses the FMOL and DOLS panel data analysis techniques to estimate import elasticities, which is an important contribution of the paper to trade openness literature.

After testing for robustness of the results, our main findings show that the average tariff rate used as a measure for trade openness is negative and inelastic with respect to aggregate and disaggregated imports. This result implies that tariff rates negatively influence demand for imports. The policy implications from this result are that governments of EAC countries should use trade openness reforms, particularly the tariff rate to minimize the importation of goods that can be produced locally. This will help in managing the balance of trade.

\subsection{Policy Recommendation}

The policy implications from this result are that governments of EAC countries should use trade openness reforms, particularly the tariff rate to minimize the importation of goods that can be produced locally. This will help in managing the balance of trade.

\subsection{Limitations of the Study}

In this study, we have found that there are a number of directions which could be explored in future research. First, the use of highly disaggregated sector specific data. This will provide a more complete picture of effects of trade openness on disaggregated import demand. Furthermore; so many others factors that influence import demand could be analysed i.e., how institutional factors such as customs procedures affect import demand. Lastly the data set used in this study covers the period in which EAC countries had implemented the EAC Customs Union i.e. 1994 to 2012, this period could be extended to cover the implementation of the EAC Common Market.

\section{References}

[1] World Bank (2012) World Development Indicators 2012. World Development Indicators. World Bank, Washington DC. 
http://documents.worldbank.org/curated/en/553131468163740875/World-develop ment-indicators-2012

[2] Blejer, M. and Cheasty, A. (1990) Fiscal Implications of Trade Liberalization. In: Tanzi, V., Ed., Fiscal Policy in Open Developing Economies, International Monetary Fund, Washington DC, 66-81.

[3] Tanzi, V. (1989) The Impact of Macroeconomic Policies on the Level of Taxation and the Fiscal Balance in Developing Countries. IMF Staff Papers, 36, 633-656. https://doi.org/10.2307/3867050

[4] Melo, O. and Vogt, M.G. (1984) Determinants of the Demand for Imports of Venezuela. Journal of Development Economics, 14, 351-358.

https://doi.org/10.1016/0304-3878(84)90064-6

[5] Mwega, F.M. (1993) Import Demand Elasticities and Stability during Trade Liberalization: A Case Study of Kenya. Journal of African Economies, 2, 381-416.

https://doi.org/10.1093/oxfordjournals.jae.a036790

[6] Omolo, S.W. (1992) Bilateral Trade between Kenya and Uganda: An Empirical Investigation. Doctoral Dissertation, University of Nairobi, Nairobi. http://erepository.uonbi.ac.ke/handle/11295/20300

[7] Santos-Paulino, A. and Thirlwall, A.P. (2004) The Impact of Trade Liberalisation on Ex-ports, Imports and the Balance of Payment of Developing Countries. The Economic Journal, Royal Economic Society, 114, F50-F72.

[8] Goldstein, M. and Khan, M.S. (1985) Income and Price Effects in Foreign Trade. Handbook of International Economics, 2, 1041-1105. https://doi.org/10.1016/S1573-4404(85)02011-1

[9] Sarmad, K. (1989) The Determinants of Import Demand in Pakistan. World Development, 17, 1619-1625. https://doi.org/10.1016/0305-750x(89)90032-6

[10] Harvey, S. and Sedegah, K. (2011) Import Demand in Ghana: Structure, Behaviour and Stability. AERC Research Paper 233.

[11] Abuka, C.A. and Ddamulira, D.M. (1999) Import Demand in Uganda: An Investigation 1987-1996. Bank of Uganda Staff Papers, 1, 47-62. https://www.bou.or.ug/bou/bou-downloads/staff.pdf

[12] Mah, J.S. (1999) Import Demand, Liberalization and Economic Development. Journal of Policy Modelling, 21, 497-503.

[13] Weiss, J. (1995) Economic Policy in Developing Countries: The Reform Agenda. Prentice Hall, Englewood Cliffs.

[14] Dutta, D. and Nasir, U.A. (2004) An Aggregate Import Demand Function for India: A Cointegration Analysis. Applied Economics Letters, 11, 607-613. https://doi.org/10.1080/1350455042000271134

[15] Aydin, M., Ciplak, U. and Yucel, E. (2004) Export Supply and Import Demand Models for the Turkish Economy. Research Department Working Paper, The Central Bank of the Re-public of Turkey, 107-123.

[16] Senhadji, A. (1998) Time-Series Estimation of Structural Import Demand Equations: A Cross-Country Analysis. IMF Staff Papers, 45, 236-268. https://doi.org/10.2307/3867390

[17] Dash, A.K. (2006) An Econometric Estimation of the Aggregate Import Demand Function for India. The ICFAI Journal of Applied Finance, 12, 30-40.

[18] Pupongsak, S. (2010) The Effect of Trade Liberalization on Taxation and Government Revenue. Doctoral Dissertation, University of Birmingham, Birmingham.

[19] Narayan, P.K. and Narayan, S. (2005) An Empirical Analysis of Fiji's Import. Journal of Economic Studies, 32, 158-168. https://doi.org/10.1108/01443580510600931 
[20] Tang, A. and Nair, M. (2002) A Cointegration Analysis of Malaysian Import Demand Function: Reassessment from the Bounds Test. Applied Economic Letters, 9, 293-296. https://doi.org/10.1080/13504850110073471

[21] Xu, X. (2002) The Dynamic-Optimizing Approach to Import Demand: A Structural Model. Economics Letters, 74, 265-270. https://doi.org/10.1016/S0165-1765(01)00538-9

[22] Ho, W.S. (2004) Estimating Macao's Import Demand Functions. Monetary Authority of Macao, 18.

[23] Clarida, H.R. (1994) Cointegration, Aggregate Consumption, and the Demand for Imports: A Structural Econometric Investigation. The American Economic Review, 84, 298-308.

[24] Gumede, V. (2000) Import Demand Elasticities for South Africa: A Cointegration Analysis. Journal for Studies in Economics and Econometrics, 24, 21-37.

[25] Ziramba, E. (2010) Price and Income Elasticities of Crude Oil Import Demand in South Africa: A Cointegration Analysis. Energy Policy, 38, 7844-7849. https://doi.org/10.1016/j.enpol.2010.08.044

[26] Baltagi, B.H. (2005) Econometric Analysis of Panel Data. 3rd Edition.

[27] Im, K.S., Pesaran, M.H. and Shin, Y. (2003) Testing for Unit Roots in Heterogeneous Panels. Journal of Econometrics, 115, 53-74. https://doi.org/10.1016/S0304-4076(03)00092-7

[28] Maddala, G.S. and Wu, S. (1999) A Comparative Study of Unit Root Tests with Panel. Data and a New Simple Test. Oxford Bulletin of Economics and Statistics, 61, 631-652. https://doi.org/10.1111/1468-0084.61.s1.13

[29] Arellano, M. and Bond, S. (1991) Some Tests of Specification for Panel Data: Monte Carlo Evidence and an Application to Employment Equations. Review of Economic Studies, 38, 277-297. https://doi.org/10.2307/2297968

Submit or recommend next manuscript to SCIRP and we will provide best service for you:

Accepting pre-submission inquiries through Email, Facebook, LinkedIn, Twitter, etc. A wide selection of journals (inclusive of 9 subjects, more than 200 journals)

Providing 24-hour high-quality service

User-friendly online submission system

Fair and swift peer-review system

Efficient typesetting and proofreading procedure

Display of the result of downloads and visits, as well as the number of cited articles

Maximum dissemination of your research work

Submit your manuscript at: http://papersubmission.scirp.org/

Or contact me@scirp.org 